\title{
Pengaruh Foreign Ownership, Loan Deposit Rasio, dan GDP Growth terhadap Net Interest Margin
}

\author{
Ardian Prima Putra \\ Universitas Veteran Bangun \\ Nunun Tri Widarwati \\ Universitas Veteran Bangun \\ Bambang Nur C \\ Universitas Veteran Bangun \\ Purwanto \\ Universitas Veteran Bangun \\ ardian.putura@gmail.com
}

\begin{abstract}
Abstrak
Penelitian ini bertujuan untuk mendapatkan bukti empiris sejumlah faktor yang dapat mempengaruhi Net Interest Margin (NIM) bank di Bursa Efek Indonesia (BEI) tahun 20132017. Faktor-faktor yang diduga dapat mempengaruhi NIM dalam penelitian ini adalah, Foreign Ownership, Loan Deposit Rasio, dan GDP Growth. Penelitian ini diharapkan bermanfaat bagi pemegang saham bank dalam mengawasi dan mengontrol manajemen bank dalam mengelola NIM bank, bagi manajemen bank dapat mengendalikan NIM pada bank tersebut, bagi pemerintah dapat menentukan kebijakan NIM bank dengan tepat, dan bagi penelitian selanjutnya dapat menambah rujukan dalam bidang penelitian perbankan khususnya NIM.Hasil penelitian ini menyatakan bahwa secara simultan variavel Foreign Ownership, Loan Deposit rasio, dan GDP Growth berpengaruh positif terhadap variabel Net Interest Margin. Secara parsial variabel Foreign Ownership berpengaruh positif terhadap NIM.
\end{abstract}

Keywords : Net Interest Margin, Foreign Ownership, Loan Deposit Rasio, dan GDP Growth

\section{Pendahuluan}

Berdasarkan Undang- undang No.10 Tahun 1998 tentang “Perubahan atas Undangundang No. 7 / 1992 Tentang Perbankan”, lembaga keuangan bank terdiri atas bank umum dan bank perkreditan rakyat. Bank umum dan bank perkreditan rakyat bisa memilih untuk melaksanakan kegiatan usahanya atas dasar prinsip Bank Konvensional atau berdasarkan prinsip syariah. Pencapaian tingkat efisiensi Bank antara lain diukur melalui rasio Biaya Operasional terhadap Pendapatan Operasional (BOPO) dan rasio Net Interest Margin (NIM) atau rasio Net Operating Margin (NOM ). Net interest margin (NIM) mencerminkan tingkat keuntungan bank dari pengelolaan aset. Keuntungan net interest margin didapatkan dari fungsi intermediasi perbankan yaitu sebagai lembaga penyalur dana dari pihak ketiga (debitur) kepada masyarakat (kreditur). Navneet et al (2009) mendefinisikan margin bunga bersih sebagai perbedaan antara suku bunga pinjaman dan deposito.

Studi Ho dan Saunder (1981) menjadi pioneer dalam analisa net interest margin dengan membuat model perbankan sebagai lembaga intermediasi antara penerima dana dan penyalur dana (dealer's model). Rasio Net Interest Margin (NIM) adalah pendapatan bunga bersih dibandingkan dengan rata-rata total aset produktif . Pengertian Net Interest Margin (NIM) menurut Abra Puspa Ghani Talattov dan FX Sugiyanto (2008) adalah "NIM merupakan 
selisih bunga simpanan (dana pihak ketiga) dengan bunga pinjaman”. Sehingga NIM merupakan unsur penting bagi perbankan. Semakin tinggi NIM maka tingkat keuntungan yang didapatkan oleh bank juga semakin tinggi. Namun demikian, pemerintah Indonesia melalui Bank Indonesia akan membatasi tingkat bunga margin bank menjadi 4\%. NIM 5 bank besar di indonesia mengalami penurunan.

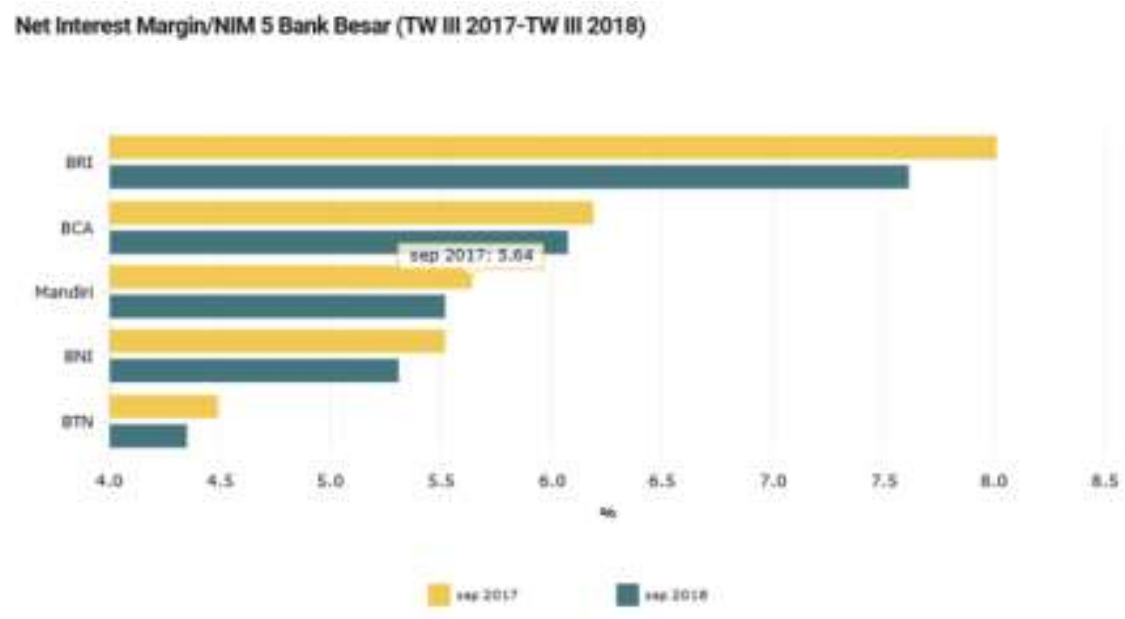

Gambar 1. Net Interest Margin (Bloomberg, 2018)

Pembatasan NIM tersebut berdasarkan data NIM perbankan di ASEAN adalah 2-4\%. Pemerintah Indonesia berharap bank nasional di Indonesia bisa bersaing dengan bank-bank di ASEAN. Disamping itu, pembatasan NIM juga untuk meringankan masyarakat Indonesia dalam hal pembebanan suku bunga kredit. NIM yang rendah dapat mengakses pasar lebih banyak bagi masyarakat Indonesia. Dengan kata lain, masyarakat lebih mudah mengakses kredit dengan suku bunga yang rendah. NIM di Indonesia masih tinggi dibanding dengan perbankan di ASEAN.

Di negara berkembang dengan pasar modal yang kurang berkembang, baik perusahaan maupun individu sering tidak punya tempat lain untuk berpaling selain pinjaman bank untuk mengumpulkan uang, yang, pada gilirannya, mungkin bahkan menghambat pertumbuhan ( Martinez Peria dan Mody, 2004 ). Selain itu, margin tinggi dapat mengindikasikan masalah dalam lingkungan perbankan regulasi dan asimetri informasi. Di sisi lain, lebih tinggi margin dapat meningkatkan profitabilitas sistem perbankan, memperkuat kapitalisasi bank dan memperkuat posisi keuangannya dengan menciptakan buffer tambahan terhadap guncangan negatif ( Barajas et al., 2000 ).

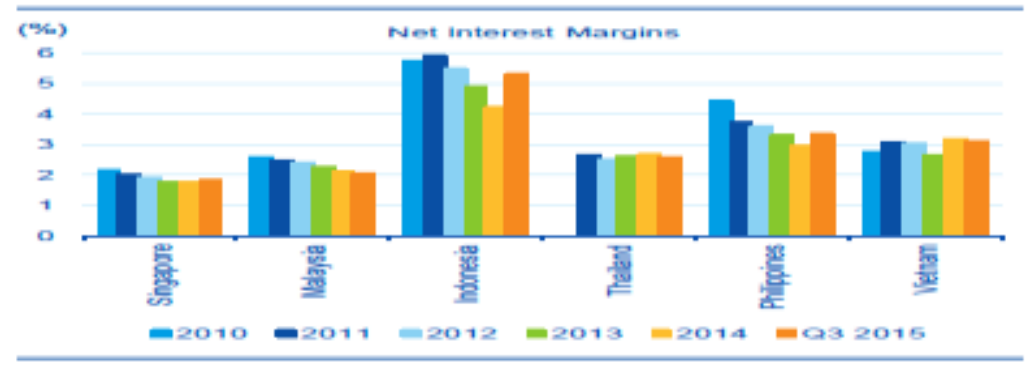

Gambar 2. Perbandingan Net Interest Margin diKawasan ASEAN Sumber: BBVA Research, Bloomberg Data, BI, BSP, BoT, 2015 
Sejumlah peneliti terdahulu baik dari luar negeri maupun Indonesia telah menemukan sejumlah faktor yang mempengaruhi NIM bank. Micco et al. (2007) menunjukkan bahwa bentuk bank kepemilikan memiliki pengaruh kuat pada kinerja bank di negara berkembang, sementara dampaknya adalah lebih lemah di negara industri. Model dealer mengasumsikan bahwa, terlepas dari kepemilikannya, bank menerapkan strategi bisnis yang serupa dan terpapar pada set margin bunga yang serupa penentu. Martinez Peria dan Mody (2004) menunjukkan bahwa bank asing di negara Amerika Latin menunjukkan margin bunga yang lebih rendah daripada bank domestik. Sebaliknya Dabla - Norris dan Floerkemier (2007) tidak menemukan hubungan langsung antara kehadiran bank asing dan margin bunga di armenia. Tan (2012) kepemilikan asing menjadi berhubungan positif dengan NIM. Kepemilikan asing biasanya melibatkan transfer teknologi, keahlian teknis, dan praktik manajemen yang lebih baik dari luar negeri. Alfanus, Kepemilikan asing berpengaruh negatif terhadap NIM .

Penelitian terdahulu menyebutkan bahwa Alihodzic dan Plakalovic (2015) menegaskan ada pengaruh yang positif dan signifikan antara likuiditas yang diproksikan oleh Loan to Deposit Ratio terhadap NIM. Gross Domestic Product (GDP) merupakan nilai keseluruhan barang, jasa, nilai tambah ekonomi dan jumlah pendapatan ekonomi dalam satu periode (Blanchard dan Johnson, 2013: 42), hasil penelitian Plakalovic dan Alihodzic (2015) mengenai Gross Domestic Product (GDP) berpengaruh positif signifikan terhadap NIM.

Berdasarkan hasil penelitian NIM terdahulu, faktor-faktor yang mempengaruhi NIM menunjukkan hasil yang berbeda. Hasil perbedaan ini menunjukkan masih adanya gap secara teori dan pengujian empiris. Selain itu, penelitian berkaitan dengan NIM menunjukkan jumlah yang terbatas bagi industri perbankan negara-negara di dunia. Demikian juga di Indonesia, penelitian NIM juga masih terbatas. Untuk itu, penulis tertarik untuk meneliti pengaruh Foreign Ownership, Loan Deposit Rasio, dan GDP Growth Terhadap Net Interest Margin ( NIM ).

Tujuan dari penelitian ini adalah untuk menemukan bukti empiris berikut ini:

1. Apakah Foreign Ownership dapat meningkatkan NIM bank di BEI tahun 20132017 ?

2. Apakah Loan to Deposit Rasio dapat meningkatkan NIM bank di BEI tahun 20132017 ?

3. Apakah GDP Growth dapat meningkatkan NIM bank di BEI tahun 2013-2017?

\section{Manfaat Penelitian}

\section{Pemegang Saham}

Penelitian ini dapat menjadi bahan pertimbangan bagi pemegang saham dalam memberikan pengawasan kepada manajemen bank untuk mencapai profitabilitas dari pendapatan Net interest margin (NIM) bank. Dengan demikian, pemegang saham dapat melihat kinerja manajemen bank dalam mengelola aktivitas operasional perbankan. Hal itu dapat mendukung kebijakan yang tepat oleh pemegang saham terkait NIM bank di Indonesia. 
INOBIS: Jurnal Inovasi Bisnis dan Manajemen Indonesia

Volume 3, Nomor 4, September 2020

Ardian Prima Putra, Nunun Tri Widarwati, Bambang Nur C Dan Purwanto

\section{Manajemen Bank}

Penelitian ini dapat menjadi bahan pertimbangan bagi manajemen bank dalam mengelola dan mengatur NIM bank dengan sejumlah faktor internal maupun risiko eksternal. Dengan demikian, manajemen bank dapat membuat keputusan yang tepat terkait kebijakan NIM bank.

\section{Pemerintah}

Penelitian ini dapat menjadi bahan pertimbangan bagi pemerintah dalam mengawasi dan mengatur net interest margin bank (NIM) di BEI. Dengan demikian, pemerintah dapat menentukan kebijakan yang tepat dalam industri perbankan. Sehingga kebijakan NIM dapat menguntungkan bagi semua pihak baik investor maupun masyarakat.

\section{Peneliti Selanjutnya}

Penelitian ini dapat menjadi bahan rujukan bagi penelitian selanjutnya terkait net interest margin (NIM) bank di Indonesia. Sehingga didapatkan pengembangan penemuan terkait NIM di Indonesia. Dengan demikian, semua pihak dapat diuntungkan dari penentuan besarnya NIM bank di Indonesia.

\section{Tinjauan Pustaka}

\section{Net Interest Margin (NIM)}

NIM adalah ringkasan untuk mengukur return bunga bersih, komponen penting dari profit bank (Angbazo, 1997). Untuk mengidentifikasi akuntansi, margin bunga bersih bank (sebelum pajak) sama dengan profit ditambah biaya operasi bank, ditambah kerugian pinjaman, dikurangi pendapatan selain bunga (Demirguc-Kunt \& Huizinga, 2000).

Kunt dkk (2003) menemukan bahwa net interest margin (NIM) dalam pinjaman tradisional dan pinjaman operasi bank mencerminkan efisiensi operasional murni dari bank dan lingkungan persaingan dari pasar perbankan. Ketidakefisien dan kondisi pasar cenderung meningkatkan biaya overhead daripada interest margin yang besar. Perbedaan diantara bank dalam interest margin mungkin mencerminkan pilihan apakah memilih biaya overhead yang tinggi atau margin yang besar daripada mencerminkan perbedaan efisiensi dan persaingan. Selanjutnya, margin bank mencerminkan alokasi aset dan tingkat risiko bank.

Tingginya NIM dapat diintepretasikan menjadi dua sudut pandang (Clayes dan Vennet, 2007). Pertama, tingginya NIM mencerminkan rendahnya tingkat efisiensi bank dan kondisi pasar perbankan yang tidak kompetitif. Kedua, tingginya interest margin mencerminkan ketidakcukupan peraturan perbankan dan tingginya asimetri informasi. Disamping itu, tingginya NIM juga mengindikasikan tingginya risiko premium, ketika kondisi persaingan meningkat maka akan mendorong perilaku spekulatif dari sistem perbankan yang dapat memimpin kestabilan keuangan (Hellman, Murdock dan Stiglitz, 2000). Foreign Ownership berpengaruh negatif terhadap kinerja (Lensink,2007). Faktor makroekonomi, yaitu, volatilitas suku bunga, inflasi dan tingkat pertumbuhan PDB, yang ditemukan mempengaruhi NIM bank di negara lain, tidak signifikan dalam konteks bank domestik Sri Lanka ( Kumari,2014). Penelitian yang lain GDP growth memiliki dampak yang kuat terhadap Net Interest Margin pada bank domestik, sedangkan GDP Growth memiliki dampak yang lemahterhadap net interest margin pada bank asing ( Hamadi,Awdeh 2012). 
INOBIS: Jurnal Inovasi Bisnis dan Manajemen Indonesia

Volume 3, Nomor 4, September 2020

Ardian Prima Putra, Nunun Tri Widarwati, Bambang Nur C Dan Purwanto

\section{Kepemilikan Asing}

Kepemilikan Asing merupakan proporsi kepemilikan saham perusahaan yang dimiliki oleh perorangan, badan hukum, pemerintah serta bagian - bagiannya yang berstatus luar negeri bukan berasal dari indonesia. prosentase kepemilikan asing pada suatu perbankan Kepemilikan asing dinyatakan dalam persen lebih dari $50 \%$ bernilai 1 dan dibawah $50 \%$ bernilai 0 . Pengukuran tersebut Dummy variabel.

\section{Loan Deposit Rasio}

Likuiditas mencerminkan kemampuan untuk membayar kewajiban keuangan jangka pendek tepat waktu (Sartono, 2010: 116). Loan to Deposit Ratio digunakan sebagai tolok ukur likuiditas bank yang diukur melalui penyaluran kredit oleh bank yang didanai oleh dana pihak ketiga. Alihodzic dan Plakalovic (2015) menegaskan ada pengaruh yang positif dan signifikan antara likuiditas yang diproksikan oleh Loan to Deposit Ratio terhadap NIM

\section{GDP Growth}

Gross Domestic Product (GDP) merupakan nilai dari barang dan jasa yang dihasilkan atau diproduksi oleh suatu negara dalam suatu periode tertentu dengan menjumlahkan semua output dari warga negara di suatu negara ditambah dengan warga negara asing yang bekerja di negara bersangkutan (Putong, 2002).

\section{Pengembangan Hipotesis}

\section{Kepemilikan Asing Dan NIM}

Claeys dan Vennet (2008) menemukan bahwa tingkat konsentrasi industri bank yang lebih tinggi maka tingkat margin bunga juga semakin tinggi. Ho dan Saunders (1981) mengatakan bahwa menghindari risiko managerial yang lebih tinggi akan meningkatkan margin bunga. Bank milik pemerintah cenderung memiliki NIM yang lebih besar daripada bank milik swasta pada perbankan di Indonesia (Trinugroho, 2014).

H1 : Kepemilikan Asing berpengaruh negatif terhadap NIM

\section{Loan Deposit Rasio Dan NIM}

Loan to Deposit Ratio digunakan sebagai tolok ukur likuiditas bank yang diukur melalui penyaluran kredit oleh bank yang didanai oleh dana pihak ketiga. Alihodzic dan Plakalovic (2015) menegaskan ada pengaruh yang positif dan signifikan antara likuiditas yang diproksikan oleh Loan to Deposit Ratio terhadap NIM. Penelitian Bagus ( 2012) LDR berpengaruh positif terhadap NIM.

H2 : Loan Deposit Rasio yang semakin besar dapat meningkatkan NIM

\section{GDP Growth Dan NIM}

Gross Domestic Product (GDP) merupakan nilai keseluruhan barang, jasa, nilai tambah ekonomi dan jumlah pendapatan ekonomi dalam satu periode (Blanchard dan Johnson, 2013: 42).Penelitian yang dilakukan oleh Alihodzic dan Plakalovic (2015) menyimpulkan terdapat pengaruh positif signifikan terhadap NIM. Berdasarkan hasil penelitian diatas, maka hipotesis penelitian adalah sebagai berikut:

H3: GDP Growth yang semakin besar dapat meningkatkan NIM 


\section{Kerangka Pemikiran}

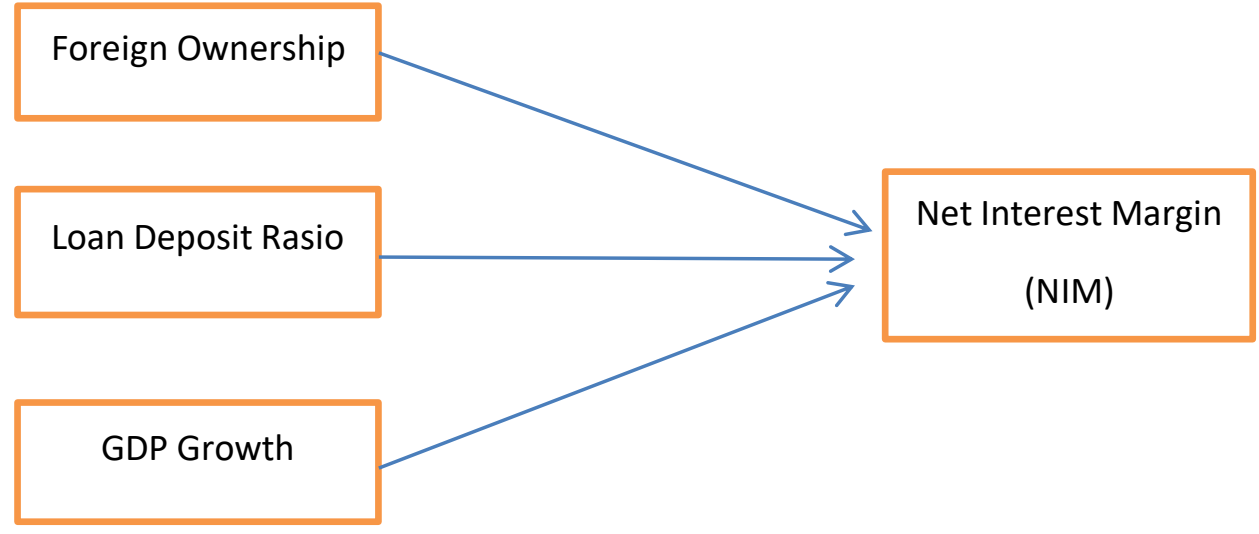

Gambar 3. Kerangka Berpikir

Sumber : Ho and Saunders (1981), Nisnaken (2010), Throsten dan Heiko (2009)

Gambar 3.1 adalah kerangka pemikiran penelitian. Gambar 3.1 menerangkan bahwa Kepemilikan Asing, Loan Deposit Rasio (LDR), GDP Growth sebagai variabel independen mempengaruhi Net interest margin (NIM) sebagai variabel dependen. Kepemilikan Asing dapat menentukan kebijakan NIM bank sehingga dapat mempengaruhi NIM. Loan Deposit Rasio (LDR) merupakan penyaluran kredit oleh bank yang didanai oleh dana pihak ketiga sehingga besarnya LDR dapat menaikan NIM bank. GDP Growth merupakan nilai keseluruhan barang, jasa, nilai tambah ekonomi dan jumlah pendapatan ekonomi dalam satu periode (Blanchard dan Johnson, 2013).

\section{Metodologi Penelitian}

\section{Desain Penelitian}

Penelitian ini menggunakan metode kuantitatif. Metode kuantitatif adalah suatu metode penelitian yang dapat dihitung dengan jumlah satuan tertentu atau dinyatakan dengan angka-angka dengan menggunakan data sekunder (Sekaran, 2006 : 65). Penelitian ini merupakan penelitian hubungan sebab akibat yaitu pengaruh variabel independen terhadap variabel dependen.

\section{Populasi, Sampel dan Teknik Sampling Penelitian}

Populasi pada penelitian ini adalah bank konvensional baik BUMN maupun swasta yang terdapat di Bursa Efek Indonesia (BEI) tahun 2013-2017. Sedangkan, teknik pengambilan sampel menggunakan metode purposif sampling yaitu pemilihan sampel dengan tujuan tertentu, kriteria atau kuota tertentu (Sekaran, 2006 : 136). Data didapatkan dari Website Bank Indonesia, OJK, BEI, dan website bank.

\section{Definisi Operasional dan Pengukuran Variabel}

\section{Net Interest Margin (NIM)}

Net Interest Margin (NIM) adalah ukuran profitabilitas bank dari fungsi intermediasi bank yaitu menghimpun dana dan menyalurkan dana. NIM adalah selisih pendapatan bunga dan biaya bunga dibagi bunga laba aset. NIM diukur dengan skala desimal karena prosentase. Rumus NIM adalah sebagai berikut: 
NIM $=\underline{\text { Pendapatan Bunga }- \text { Biaya Bunga }}$

Bunga Laba Aset

\section{Foreign Ownership}

Kepemilikan Asing merupakan proporsi kepemilikan saham perusahaan yang dimiliki oleh perorangan, badan hukum, pemerintah serta bagian - bagiannya yang berstatus luar negeri bukan berasal dari indonesia. prosentase kepemilikan asing pada suatu perbankan Kepemilikan asing dinyatakan dalam persen lebih dari $50 \%$ bernilai 1dan dibawah $50 \%$ bernilai 0 . Pengukuran tersebut Dummy variabel.

\section{Loan Deposit Rasio ( LDR)}

Loan to Deposit Ratio adalah perbandingan kredit disalurkan olehbank pada nasabah dibanding jumlah/total dana pihak ketiga (DPK). Besarnya LDR dirumuskan sebagai berikut dan dinyatakan dalam persen (\%) (Kasmir, 2011)

$\mathrm{LDR}=\underline{\text { Total kredit }} \times 100 \%$

Total dana Pihak ke tiga

\section{GDP Growth}

GDP growth merupakan pertumbuhan output produksi pada suatu wilayah tertentu dalam hal ini GDP Indonesia periode 2013-2017. Besarnya GDP growth dirumuskan sebagai berikut dan dinyatakan dalam persen (\%) (Sukirno, 2011)

$\mathrm{G}=\underline{\mathrm{GDP}} 1-$ GDP $0 \times 100 \%$

GDP 0

\section{Teknik Analisis Data}

1. Analisis Regresi

Teknik analisis data yang digunakan adalah analisis regresi berganda, karena variabel independen dalam penelitian ini berjumlah lebih dari satu. Teknik analisis regresi berganda merupakan teknik uji yang digunakan untuk mengetahui pengaruh variabel independen terhadap variabel dependen. Persamaan regresi linier berganda adalah

$\mathrm{YNIM}=\alpha+\beta 1 \mathrm{FM}+\beta 2 \mathrm{LDR}+\beta 3 \mathrm{GDP}+\mathrm{e}$

Keterangan :

$$
\begin{array}{ll}
\text { Y Nim } & =\text { Variabel Dependen Net Interest Margin } \\
\alpha & =\text { Konstanta } \\
\beta & =\text { Koefisien Variabel Independen } \\
\text { FM } & =\text { Kepemilikan Asing } \\
\text { LDR } & =\text { Loan Deposit Rasio } \\
\text { GDP } & =\text { Product Domestic Bruto } \\
\text { Size } & =\text { Ukuran Bank }
\end{array}
$$


INOBIS: Jurnal Inovasi Bisnis dan Manajemen Indonesia

Volume 3, Nomor 4, September 2020

Ardian Prima Putra, Nunun Tri Widarwati, Bambang Nur C Dan Purwanto

$\mathrm{e} \quad=$ eror

2. Uji Hipotesis

Uji Hipotesis bertujuan untuk mengetahui hipotesis yang digunakan dalam penelitian diterima atau ditolak. Uji hipotesis terdiri dari tiga macam adalah uji F statistik, uji koefisien determinasi (R2), dan uji t. Berikut ini ketiga macam uji hipotesis tersebut:

a. Analysis of Variance (ANOVA)/ Uji F Statistik

Uji F digunakan untuk mengetahui pengaruh signifikansi variabel-variabel independen secara simultan terhadap variabel dependen. Derajat signifikansi kepercayaan yang digunakan dalam penelitian ini adalah 0,05 . Apabila nilai $F$ hasil perhitungan lebih besar daripada nilai $F$ tabel maka semua variabel independen secara simultan berpengaruh signifikan terhadap variabel dependen. Atau Apabila nilai signifikansi variabel independen terhadap variabel dependen lebih kecil dari 0,05 maka variabel independen secara signifikan berpengaruh terhadap variabel dependen.

b. Koefisien Determinasi (R2) atau R Square

Uji Koefisien Determinasi menunjukkan bahwa seberapa besar variabel independen dapat mempengaruhi atau menjelaskan variabel dependen yang digunakan dalam penelitian.

c. Uji t Statistik

Uji T digunakan untuk mengetahui pengaruh signifikansi variabel-variabel independen secara parsial terhadap variabel dependen.

\section{Hasil dan Pembahasan}

\section{Analisis Data}

Berdasarkan pengolahan data pada bab metode penelitian di bab sebelumnya, dihasilkan beberapa hasil analisis data yang menjawab permasalahan pada penelitian ini. Hasil analisis data yang dihasilkan berdasarkan pada tujuan penelitian ini. Tujuan penelitian ini adalah untuk menguji secara empiris pengaruh foreign ownership, loan deposit rasio, dan GDP growth terhadap net interest margin.

\section{Data Sampel Penelitian}

Data sampel yang digunakan dalam penelitian ini adalah 32 Bank di Indonesia yang terdiri dari 4 Bank BUMN dan 10 Bank Swasta di Indonesia pada tahun 2013-2017. Sejumlah 14 bank itu merupakan bank yang terdaftar di BEI maupun tidak terdaftar di BEI. Dalam Penelitian ini diperoleh 70 data observasi pada tahun 2013-2017. Data penelitian ini lolos uji asumsi klasik yang meliputi normalitas, heteroskedastisitas, autokorelasi dan multikolonieritas.

\section{Statistik Deskriptif}

Analisis statistik deskriptif digunakan untuk melihat gambaran atau deskripsi data yang digunakan sebagai sampel. Berdasarkan tabel di bawah menunjukkan jumlah data yang digunakan dalam penelitian ini adalah sebanyak 70 data. Berdasarkan output spss diperoleh hasi data sebagai berikut: 


\section{Net Interest Margin}

Variabel Net interest margin memiliki nilai rata-rata sebesar 5,9526 dengan standar deviasi sebesar 2,26381. Standar deviasi yang lebih kecil dari nilai rata-rata menunjukkan bahwa sebaran data variabel kecil dan tidak ada kesenjangan besar.

\section{Tabel 1 Descriptive Statistics}

\begin{tabular}{lrrr}
\hline & \multicolumn{3}{c}{ Std. } \\
& \multicolumn{1}{c}{ Mean } & Deviation & \multicolumn{1}{l}{$\mathrm{N}$} \\
\hline nim & 5,9526 & 2,26381 & 70 \\
foreign & 47,7711 & 27,13501 & 70 \\
ldr & 89,2230 & 7,97038 & 70 \\
gdp & 5,1800 &, 28410 & 70 \\
\hline
\end{tabular}

2. Foreign

Sumber : (spss, 2019)

Variabel Foreign Ownership memiliki nilai rata-rata 47,7711 dengan standar deviasi sebesar 27,13501. Standar deviasi yang lebih kecil dari nilai rata-rata menunjukkan bahwa sebaran data variabel kecil dan tidak ada kesenjangan besar.

3. Loan Deposit Ratio

Variabel LDR memiliki nilai rata-rata sebesar 89,2230 dengan standar deviasi sebesar 7,97038. Standar deviasi yang lebih kecil dari nilai rata-rata menunjukkan bahwa sebaran variabel kecil dan tidak ada kesenjangan besar.

4. Growth Domestic Product

Variabel GDP memiliki nilai rata-rata sebesar 5,1800 dan standar deviasi sebesar 0,28410 . Standar deviasi yang lebih kecil dari nilai-rata-rata menunjukkan bahwa sebaran data variabel kecil dantidak ada kesenjangan besar.

\section{Uji Normalitas}

Uji Normalitas dilakukan untuk memenuhi asumsi regresi yang baik apabila residual nilai taksiran model regresi berdistribusi normal.Uji normalitas model regresi ini menggunakan P-Plot /normal Probability plot dengan dasar pengambilan keputusan jika data menyebar disekitar garis diagonal dan mengikuti arah garis diagonal maka menunjukan pola distribusi normal, maka regresi memenuhi asumsi normalitas dan sebaliknya (Ghozali,2011). Hasil uji normalitas menggunakan normal probability plot adalah sebagai berikut:

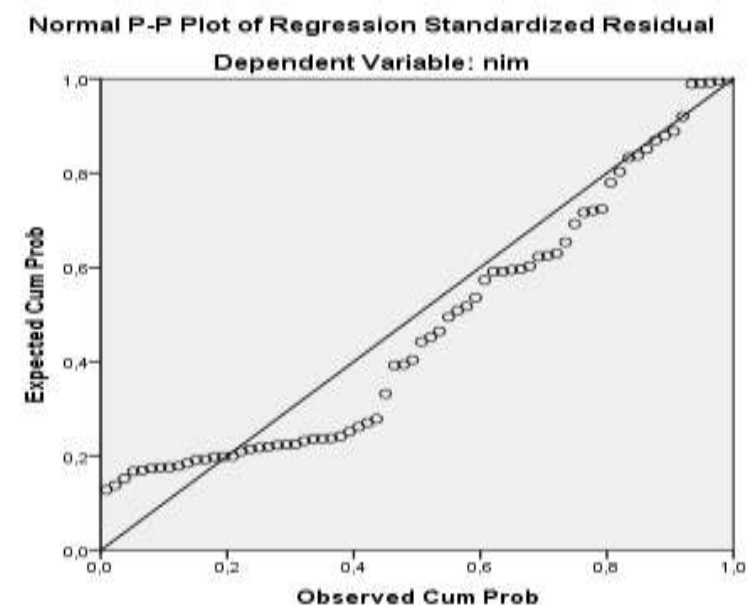

Gambar 4. Normal P-Plot 
Gambar 3 menunjukkan bahwa data menyebar di sekitar garis diagonal dan mengikuti arah garis diagonal, dan menunjukkan pola distribusi normal, sehingga dapat disimpulkan bahwa asumsi normalitas telah terpenuhi.

Uji Asumsi Klasik

Uji Asumsi klasik dalam penelitian ini menggunakan uji multikolonieritas, Uji autokorelasi, dan uji heteroskedastisitas ( Ghozali,2011).

Uji Multikolonieritas

Uji Multikolonieritas bertujuan untuk menguji apakah model ditemukan adanya korelasi antar variabel bebas ( independen). Pengujian ada tidaknya multikolonieritas di dalam model dapat diketahui dari nilai tolerance dan nilai VIF ( variance inflation Factor). Kriteria untuk dapat dinyatakan tidak terjadi gejala multikolonieritas adalah apabila nilai tolerance $\geq 0,10$ dan nilai VIF $\leq 10$. Hasil uji multikolonieritas adalah sebagai berikut:

Tabel 2 Hasil uji Multikolonieritas

\begin{tabular}{llc}
\hline Model & Tolerance & Collinearity Statistics \\
& 0,644 & VIF \\
\hline Foregin & 0,642 & 1,553 \\
LDR & 0,997 & 1,557 \\
GDP & 1,003 \\
\hline
\end{tabular}

Sumber: data yang diolah(2019)

Dari tabel 2 menunjukkan bahwa dari ketiga variabel independen ( Foreign,LDR,dan GDP ) memiliki nilai tolerance $\geq 0,10$ dan nilai VIF dari ketiga variabel $\leq 10$, maka dapat disimpulkan bahwa model regresi yang digunakan dalam penelitian ini tidak terjadi multikolonieritas.

\section{Uji Autokorelasi}

Uji Autokorelasi bertujuan untuk menguji model regresi linier ada tidaknya korelasi antara kesalahan pengganggu pada periode saat ini dengan kesalahan pengganggu pada periode sebelumnya. Pengujian ini dilakukan dengan perhitungan Durbin-Watson Test. Nilai Durbin Watson yang digunakan dalam penelitian ini (Gujarati, 37:2009) adalah daerah yang tidak terjadi autokorelasi baik positif maupun negatif yaitu $\mathrm{du}<\mathrm{d}<4$-du.

Tabel 3 Model Summary ${ }^{b}$

\begin{tabular}{|c|c|c|c|c|c|}
\hline \multirow[b]{2}{*}{ Model } & \multirow[b]{2}{*}{$\mathrm{R}$} & \multirow[b]{2}{*}{ R Square } & \multicolumn{3}{|c|}{ Std. Error } \\
\hline & & & $\begin{array}{l}\text { Adjusted } \\
\text { R Square }\end{array}$ & $\begin{array}{l}\text { of the } \\
\text { Estimate }\end{array}$ & $\begin{array}{l}\text { Durbin- } \\
\text { Watson }\end{array}$ \\
\hline 1 &, $339^{\mathrm{a}}$ &, 115 &, 075 & 2,17779 & 2,145 \\
\hline
\end{tabular}

a. Predictors: (Constant), gdp, foreign, ldr

b. Dependent Variable: nim

Tabel 3 menunjukkan Nilai DW statistik sebesar 2,145 dan nilai tersebut berada antara $(\mathrm{du}=1,7028)$ dan $(4-\mathrm{du}=2,2972)$ sehingga masuk daerah bebas autokorelasi.

Uji Heteroskedatisitas

Analisis Heteroskedatisitas dilakukan untuk mengetahui perbedaan variance residual data dari observasi satu ke observasi yang lain . Apabila variance residual data sama maka 
data tersebut Homoskedatisitas. Model regresi yang baik menggunakan data yang bersifat heteroskedastisitas. Analisis heteroskedastisitas terlihat pada gambar di bawah Ini:

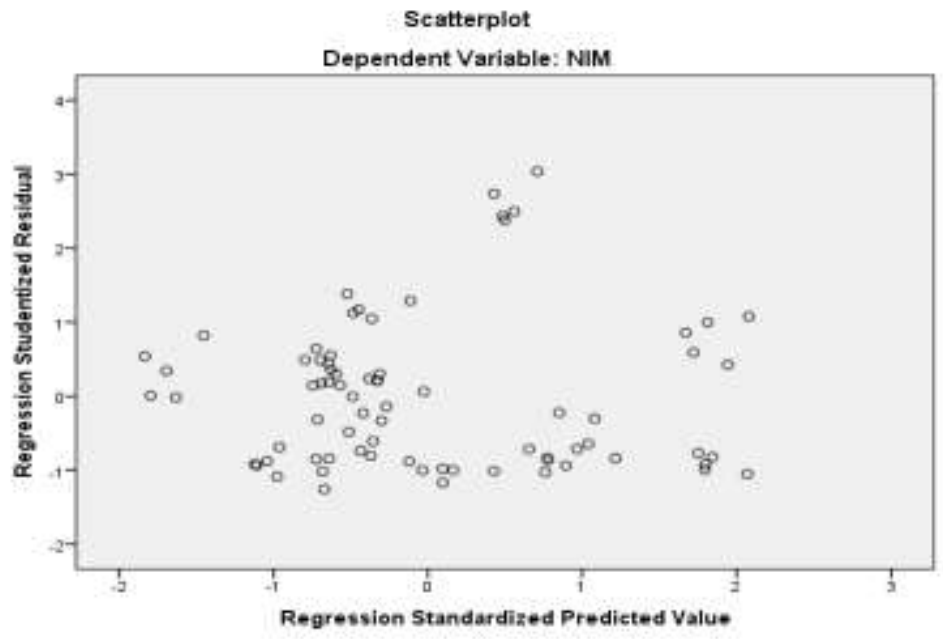

Gambar 5. Scatterplot NIM

Berdasarkan gambar 4 , Scatterplot menyebar secara acak dan tidak berkumpul pada suatu tempat. Dengan demikian, data variabel NIM memenuhi uji asumsi heteroskedastisitas.

\section{Analisis Data Dan Pembahasan}

\section{Koefisien Determinasi}

Tabel 4 Model Summary ${ }^{b}$

\begin{tabular}{|c|c|c|c|c|c|}
\hline \multirow[b]{2}{*}{ Model } & \multirow[b]{2}{*}{$\mathrm{R}$} & \multirow[b]{2}{*}{ R Square } & \multicolumn{3}{|c|}{ Std. Error } \\
\hline & & & $\begin{array}{l}\text { Adjusted } \\
\text { R Square }\end{array}$ & $\begin{array}{l}\text { of the } \\
\text { Estimate }\end{array}$ & $\begin{array}{l}\text { Durbin- } \\
\text { Watson }\end{array}$ \\
\hline 1 & $.339^{\mathrm{a}}$ & .115 & .075 & 2,17779 & 2,145 \\
\hline
\end{tabular}

a. Predictors: (Constant), gdp, foreign, ldr

b. Dependent Variable: nim

Berdasarkan tabel 4, nilai adjusted R square (koefisien determinasi) sebesar 0,075 yang memiliki arti bahwa pengaruh variabel GDP,Foreign, dan LDR terhadap NIM sebesar 7,5\%, sedangkan sisa sebesar 92,5\% dipengaruhi oleh variabel lain diluar model penelitian ini.

\section{Uji F}

Tabel 5 ANOVA ${ }^{a}$

\begin{tabular}{lrrrrrr}
\hline & & Sum of & & \multicolumn{1}{c}{ Mean } & \\
\multicolumn{1}{l}{ Model } & Squares & \multicolumn{1}{c}{ df } & Square & \multicolumn{1}{c}{ F } & \multicolumn{1}{c}{ Sig. } \\
\hline 1 & Regression & 40,592 & 3 & 13,531 & 2,853 &, $044^{\mathrm{b}}$ \\
& Residual & 313,022 & 66 & 4,743 & & \\
& Total & 353,615 & 69 & & & \\
\hline
\end{tabular}

a. Dependent Variable: nim

b. Predictors: (Constant), gdp, foreign, ldr 
Tabel 5 menunjukkan bahwa nilai $\mathrm{F}$ hitung statistik sebesar 2,853 dengan nilai signifikansi sebesar 0,044. Nilai signifikansi $0,044<0,05$ maka pengaruh variabel foreign,LDR,dan GDP terhadap Net Interest Margin adalah signifikan positif. Variabel independen secara simultan berpengaruh signifikan positif terhadap NIM.

\section{Uji t}

Tabel 6 Coefficients ${ }^{\mathrm{a}}$

\begin{tabular}{|c|c|c|c|c|c|c|c|}
\hline \multirow[b]{2}{*}{ Model } & \multicolumn{2}{|c|}{$\begin{array}{l}\text { Unstandardized } \\
\text { Coefficients }\end{array}$} & \multirow[t]{2}{*}{$\begin{array}{c}\text { Standardi } \\
\text { zed } \\
\text { Coefficie } \\
\text { nts } \\
\text { Beta }\end{array}$} & \multirow[b]{2}{*}{$\mathrm{t}$} & \multirow[b]{2}{*}{ Sig. } & \multicolumn{2}{|c|}{$\begin{array}{l}\text { Collinearity } \\
\text { Statistics }\end{array}$} \\
\hline & B & Std. Error & & & & Tolerance & VIF \\
\hline (Constant) & ,688 & 6,006 & &, 115 & ,909 & & \\
\hline foreign & ,024 & 012 & 283 & 1,959 & 054 & ,644 & 1,553 \\
\hline ldr &, 022 & ,041 & 079 & ,545 & ,588 & ,642 & 1,557 \\
\hline gdp & ,414 & ,924 &, 052 & ,448 & 656 & ,997 & 1,003 \\
\hline
\end{tabular}

a. Dependent Variable: nim

Berdasarkan hasil analisis dari tabel di atas diketahui bahwa model regresi linier ganda adalah :

\section{$Y_{\mathrm{Nim}}=0,688+0,024$ Foreign $+0,022 \mathrm{Ldr}+0,414$ GDP}

Tabel 6 menunjukkan bahwa nilai signifikansi Foreign,ldr dan gdp lebih besar dari 0,05, Bi Rate, Exchange Rate, dan ROE lebih besar dari 0,05. Dari hasil itu diketahui bahwa variabel foreign,ldr, dan gdp tidak berpengaruh terhadap NIM namun foreign ownership berpengaruh signifikan pada tingkat kesalahan/ alpha $10 \%$. Nilai t variabel foreign sebesar 1,959 dengan signifikansi 0,054 maka dapat diartikan bahwa foreign ownership bank berpengaruh signifikan positif terhadap NIM pada tingkat kesalahan $10 \%$. Hasil analisis ini menunjukkan bahwa variabel foreign ownership memiliki pengaruh positif dan signifikan pada NIM, sehingga dapat disimpulkan $\mathrm{H} 1$ diterima pada pada tingkat kesalahan $10 \%$ yang artinya apabila kepemilikan asing naik maka NIM juga akan mengalami kenaikan. Nilai t variabel LDR sebesar 0,545 dengan signifikansi 0,588 maka dapat diartikan bahwa LDR tidak berpengaruh signifikan terhadap NIM. Apabila nilai LDR meningkat maupun turun maka tidak ada pengaruh terhadap Net interest margin. Nilai t variabel GDP sebesar 0,448 dengan signifikansi sebesar 0,656 maka dapat diartikan bahwa GDP tidak berpengaruh signifikan terhadap NIM pada tingkat signifikansi $10 \%$ maupun $5 \%$. Apabila GDP naik maupun turun tidak akan mempengaruhi NIM. Hasil penelitian berbeda dengan Trinugroho (2014) bahwa kepemilikan pemerintah berpengaruh positif terhadap NIM. Namun mendukung hasil penelitian Ho dan Saunders (1981) bahwa Kepemilikan asing (foreign ownership) berpengaruh positif terhadap NIM. Hasil Penelitian tidak mendukung penelitian Bagus (2012) dan Blanchard dan Johnson (2013) bahwa GDP dan LDR signifikan positif terhadap NIM.

\section{Kesimpulan}

Penelitian menemukan bahwa secara simultan variabel foreign, LDR, dan GDP berpengaruh signifikan terhadap NIM Bank di Indonesia. Faktor makro bank tidak berpengaruh terhadap jumlah NIM bank di Indonesia Faktor Intern bank lebih berpengaruh terhadap NIM daripada faktor makro. Hal ini dapat diketahui dari hasil variabel faktor intern bank yaitu 
foreign ownership yang dapat mempengaruhi NIM bank di indonesia. Secara parsial variabel Foreign ownership berpengaruh signifikan terhadap NIM pada tingkat kesalahan $10 \%$.

\section{Saran}

Manajemen bank hendaknya berperan aktif dalam menjalankan peran intermediasi perbankan sehingga dapat meningkatkan NIM bagi perusahaan. Manajemen bank yang baik dapat meningkatkan NIM. Penelitian selanjutnya tentang faktor yang mempengaruhi NIM hendaknya mempertimbangkan periode waktu yang lebih lama sehingga didapatkan observasi sampel yang lebih banyak. Selain itu, juga perlu mempertimbangkan faktor lain dari penelitian ini.

\section{Daftar Pustaka}

Alihodzic, Almir \& Plakalovic, Novo. (2016). Determinants of credit growth to nonfinancial companies in B\&H. Industrija. 44. 85-100. 10.5937/industrija44-10309.

Angbazo, L. 1997. Commercial Bank Net Interest Margin, Default Risk, Interest Rate Risk and Offbalance sheet Banking. Journal of Banking and Finance 21, 55-87.

Ariefianto, Moch Doddy dan Soepomo, Soenartomo. 2011. General and specific behavior of interest margin: evidence from post crisis Indonesian Banking. Journal of Arts, Science \& Commerce. E-ISSN 2229-4686. ISSN 2231-4172

Bagus, 2012, Konsep-Konsep Penelitian: http://annebagus.blogspot.com/2012/10/konsepkonsep-penelitian.html.

Barajas, Adolfo; Roberto Steiner and Natalia Salazar, (2000), The impact of liberalization and foreign investment in Colombia's financial sector, Journal of Development Economics, 63, (1), 157-196.

Blanchard, Olivier dan David, R. Johnson. 2013. Macroeconomics Global Edition Sixth Edition. England: Pearson.

Bloomberg. (2018). Net Interest Margin.

Claeys, S., Vennet, R.V., 2008. Determinants of bank interest margins in Central and Eastern Europe: a comparison with the West. Econ. Syst. 32, 197-216.

Drakos, K., 2003. Assessing the success of reform in transition banking 10 years later: an interest margins analysis. J. Policy Model. 25, 309-317.

Dumicic, Mirna; Ridzak, Tomislav. 2013. Determinant of Bank Net Interest Margins In Central And Eastern Europe. Financial Theory And Practice. Vol 37 (I) 1-30

Fungá cová, Z., Poghosyan, T., 2011. Determinants of bank interest margins in Russia: does bank ownership matter? Econ. Syst.35, 481-495.

Gelos, R. Gaston, "Banking Spreads in Latin America," IMF Working Paper, 2006, WP/06/44.

Hamadi, Hassan \& Awdeh, Ali. (2012). The Determinants of Bank Net Interest Margin: Evidence from the Lebanese Banking Sector. Journal of Money, Investment and Banking. 23. 85-98.

Hellmann, Thomas, F., Kevin C. Murdock, and Joseph E. Stiglitz. 2000. "Liberalization, Moral Hazard in Banking, and Prudential Regulation: Are Capital Requirements Enough?" American Economic Review, 90 (1): 147-165.

Ho, T., Saunders, A., 1981. The determinants of bank interest margins: theory and empirical evidence. J. Financial Quant. Anal. 16,581-600.

Honohan, Patrick, "Financial Development, Growth and Poverty: How Close Are the Links?" In Charles Goodhart, ed. Financial Development and Economic Growth: Explaining the Links. 2004, London: Palgrave. 
Ikhide, Sylvanus dan Yinusa, Olalekan. 2012. Why is the cost of financial intermediation rising in botswana?. The Journal Developing Area,Volume 46, No. 1 Spring 2012.

Kumari, SM Susanti Medha. (2014) Determinants of Interest Margins of Banks in Sri Lanka. South Asia Economic Journal, vol. 15, issue 2, 265-280

Kunt, A. Demirgiiu; Laeven, Luc; Levine, Ross. 2003. The Impact of Bank Regulations, Concentration, and Institutions on Bank Margins. Policy Research Working Paper 3030 .

Lensink, B.W. \& Hermes, Niels. (2007). Impact of Microfinance: A Critical Survey. Economic and Political Weekly 10 (2007). 10. 10.2307/4419226.

Maria Martinez Peria and Ashoka Mody, (2004), How foreign participation and market concentration impact bank spreads: evidence from Latin America, No 3210, Policy Research Working Paper Series, The World Bank

Micco, A., Panizza, U., Yanez, M., 2007. Bank ownership and performance. Does politics matter? J. Bank. Finance 31, 219-241.

Navneet, Seetaram; Boopen, Seetanah; Shalini, Ramessur \& Sawkut, Rojid. 2009. Determinants of Interest Rate Spread in Mauritius, The Business Review, Cambridge Vol. 14. Mauritius:University of Technology, Mauritius

Niskanen, Mervi;Niskanen, Jyrki. 2010. Small Business Borrowing and the Owner-Manager Agency Costs: Evidence on Finish Data. Journal of Small Business Management; Jan 2010; 48, 1; ABI/INFORM Research pg. 16

Poghosyan, T., 2010. Re-examining the impact of in emerging markets. Emerg. Markets Rev. 11, 390-403.

Sartono, Agus. (2010). Manajemen Keuangan Teori dan Aplikasi. Yogyakarta : BPFE

Talattov, Abra Puspa Ghani And FX Sugiyanto, Fx Sugiyanto (2011) Analisis Struktur, Perilaku Dan Kinerja Industri Perbankan Di Indonesia Tahun 2003-2008 (StructureConduct-Performance Approach Vs Relative Efficiency Approach). Undergraduate Thesis, Universitas Diponegoro.

Thorsten Beck and Heiko Hesse, (2009), Why are interest spreads so high in Uganda?, Journal of Development Economics, 88, (2), 192-204

Trinugroho, I; Agusman, A; Tarazi, Amine. 2014. Why Net Interest Margin So High In Indonesia Since The 1997/1998 Financial Crisis. Research In International Business And Finance. Vol 32, 139-158. 